\title{
ON THE NATURE
}

OF THE

\section{WAXY, LARDACEOUS, OR AMYLOID DEPOSIT.}

BX

WILLIAM H. DICKINSON, M.D. CaNTaB., F.R.C.P., ASSISTANT-PHYSICLAN TO ST. GEORGE'S HOSPITAL AND TO THE HOSPITAL FOR SICK OHIUDREN.

Received Nov. 30th, 1866.-Read Feb. 12th, 1867.

THis disease, which was little noticed when described as waxy, lardaceous, or scrofulous, has of late years received much attention under the term "amyloid." It is not necessary to repeat what is already known with regard to the nature of the change. It is not limited to one organ; but many may become thus affected at the same time or in quick succession. A morbid deposit first appears in the walls of the small arteries, then penetrates their coats, and subsequently infiltrates the neighbouring tissues.

The small arteries, the walls of which are the seat of this deposition, acquire a peculiar reaction with iodine, a test by which they can be at once distinguished. Instead of the yellow colour which solutions of iodine give to all the healthy tissues, a deep reddish brown is produced by such solutions upon the affected vessels. It has been stated by Virchow 
that, by a dexterous adjustment of sulphuric acid and iodine, a blue tint may be given to the " amyloid" deposit, but, like many other observers, I have never succeeded in obtaining any colour but reddish brown, merging into shades of dirty black. This colour, due to the precipitation of the iodine by the acid, would probably never have been looked upon as blue except by a person whose impartiality of observation had been warped by a desire to connect the morbid change with the production of starch.

Besides the change in the small arteries, which is the primary alteration, the several organs are affected, each in a manner peculiar to itself, by the exudation which the diseased vessels pour out. The solid viscera, such as the liver, spleen, and kidney, are increased in bulk, and, as best seen in the spleen and liver, become infiltrated with a new material which renders them firm, grey, and semi-transparent, characters which have suggested the term "waxy" as descriptive of the disease. A similar action taking place in the mucous membranes does not cause increase of bulk, but the exudation seems to pass, as a secretion, from the free surface of the membrane thus affected.

The new deposit, as may be clearly seen in sections of the kidney, is found to lie in abundance around the vessels from which it has exuded, and to permeate more or less the whole structure of the gland. This new formation readily becomes converted into fibrous tissue. Where seen in bulk it soon assumes, under the microscope, a fibro-nucleated structure, and its presence in small amount is evinced by a thickening of all the fibrous structures with which it comes in contact. After its deposition it undergoes a regular process of contraction, as is evinced by the changes which take place in the parts involved. The new material occasionally gives the same reactions as the affected vessels. In some cases the fibrinous casts, which lie in numbers in the tubes, give the reaction in a very striking manner (see Plate I). The matter which infiltrates the gland appears to be identical in all respects with that which forms the casts; the only difference is in the position of the vessels from which the 
exudation takes place. The vessels which are imbedded in the tissue are the source of one exudation, while the exposed Malpighian tufts supply the other: the matter from one source runs into the tissue, from the other into the tubes. Whether it appear in one place or the other it is evident that the exudation is essentially the same.

Organs affected by this disease have been repeatedly subjected to ultimate analysis. I may here refer to the valuable researches ${ }^{1}$ of Drs. Pavy and Odling. The results prove, beyond question, that the addition to their substance is either albuminous or fibrinous. The facts which have been stated regarding the new growth, its convertibility into fibrous tissue, its contractile tendency, and its apparent identity with fibrinous casts, appear to prove that it is essentially fibrinous.

It is my purpose at present to consider the disease in its general relations, rather than as affecting any organ in particular.

It is evident from the number of organs affected at the same time that the "amyloid" deposit is the result of an agency ubiquitous and simultaneous through the system. It is known that the change is apt to occur after exhausting diseases, particularly such as are syphilitic or scrofulous in their nature, and such as concern bone. Dr. Wilks² associates the disease with "long-standing and deep-seated cachexia," such as proceeds from tubercular or syphilitic disease, particularly if it affect bone. Dr. Grainger Stewart, who has collected many cases, associates the disorder with scrofula, caries, necrosis, and syphilis, or with feebleness of constitution without palpable disease.

I hope to be able to show that, whatever the nature of the antecedent disease may be, there is one definite process, common to many disorders, which is the great cause of the morbid deposit.

I have been able to collect from my own experience, in the dead-house and elsewhere, the particulars of sixty cases of

$$
\begin{aligned}
& 1 \text { 'Guy's Hospital Reports,' } 1864 . \\
& 2 \text { 'Guy's Hospital Reports,' } 1865 .
\end{aligned}
$$


this disease. I can answer for the state of the organs after death in the whole number. The circumstances of the case during life have in some instances come under my own knowledge, while in others I have obtained a more or less complete history from the St. George's Hospital records, and other sources. The following table gives the nature of the disorder which, in each case, was suicceeded by the waxy or "amyloid" infiltration.

\section{TABLE I.}

Analysis of sixty cases of so-called "amyloid" or "waxy" degeneration, which have come under the observation of the author, showing the affections by which the change has been preceded.

\begin{tabular}{|c|c|c|c|c|c|}
\hline Direct evidence of suppuratio & & Presumption of suppuration & & $\begin{array}{l}\text { No evidence relating to } \\
\text { suppuration. }\end{array}$ & \\
\hline $\begin{array}{c}\text { Exposed bone from } \\
\text { caries or necrosis, } \\
\text { with long-con- } \\
\text { tinued purulent dis- } \\
\text { charge ................ } \\
\text { Disease of spine, with } \\
\text { psoas abscess ...... } \\
\text { Profuse suppuration, } \\
\text { connected with am. } \\
\text { putation of thigh.... } \\
\text { Suppuration conse- } \\
\text { quent upon com. } \\
\text { pound fracture of } \\
\text { leg.................... } \\
\text { Phthisis with vomicæ } \\
\text { Dilated bronchi with } \\
\text { profuse purulent } \\
\text { expectoration ....... } \\
\text { Ulcerated cancer ....... } \\
\text { Ulceration of bowel, } \\
\text { including dysen. } \\
\text { tery .................. } \\
\text { Destruction of kidney } \\
\text { by tubercular exca- } \\
\text { vation (1 case caus- } \\
\text { ing psoas abscess). } \\
\text { Severe syphilitic ul. } \\
\text { ceration of throat } \\
\text { or penis ............. }\end{array}$ & $\begin{array}{r} \\
18 \\
1\end{array}$ & $\begin{array}{c}\text { Phthisis with exten- } \\
\text { sive cicatrices ... } \\
\text { Disease of elbow. } \\
\text { joint, for which } \\
\text { arm was ampu- } \\
\text { tated ............... } \\
\text { Extensive disease of } \\
\text { spine with much } \\
\text { curvature and loss } \\
\text { of bone ................... }\end{array}$ & 2 & $\begin{array}{l}\text { Cause unknown... } \\
\text { Following diseases } \\
\text { produced by } \\
\text { tropical climate } \\
\text { Apparently, con- } \\
\text { sequent upon } \\
\text { albumin uria, } \\
\text { "tubal nephri- } \\
\text { tis"............... }\end{array}$ & $\begin{array}{l}5 \\
1\end{array}$ \\
\hline Total............ & 46 & Total .......... & $\mathbf{4}$ & Total ....... & 10 \\
\hline
\end{tabular}


In fifty cases the change appeared to be associated with the formation of pus; in fourwith the loss of albumen by the urine. In the remaining six the source of the disease was not traced.

In further detail there were forty-six cases in which there was evidence of a profuse and long-continued drain of pus. In most of these the discharge persisted until the death of the patient. In four the post-mortem appearances were such as to lead to the inference that a discharge of pus had taken place at some remote period; in two there had been tubercular disease of the lungs with extensive cicatrices ; in two, destruction of bone by disease of uncertain character.

Excepting in the concurrence of suppuration with the "amyloid" deposit these cases have no resemblance to each other. Syphilis had existed in some, tubercular deposit in others ; ${ }^{1}$ while in some there was no evidence of any constitutional disease.

Of the ten remaining cases, in which there was no evidence implying the loss of pus, there were four in which there was reason to believe that the "amyloid" change had followed upon albuminuria. The albuminuria, in each case, was of the kind which is associated with tubal nephritis, and which is characterised by a large discharge of albumen. In two of the cases the urine also contained pus, though in small quantity, which apparently had been secreted by the renal tubes.

In these four cases it may be mentioned that the "amyloid" change was in an early stage, in three of them confined to the kidney.

The practical and pathological importance of the conclusion that associates the "amyloid" deposit with the suppurative process has led me to search the recorded experience of other observers for evidence in confirmation or correction of this view.

Dr. Wilks has published two papers containing the par-

'It may be worth while to state that in these 60 cases there was a history of syphilis in 4, in each of which there was either extensive destruction of soft parts, or necrosis with prolonged suppuration. The eases in which cancer or tubercles were present are sufficiently indicated in the table. 
ticulars of ninty-six cases of this disease. A statement of the causes to which he has traced the disorder is given in a table.

\section{TABLE II.}

Analysis of ninety-six cases of waxy or lardaceous disease, showing the disorders by which it has been preceded. Cases published by Dr. Wilks, in ' Guy's Hospital Reports' for 1856 and 1865.

\begin{tabular}{|c|c|c|c|c|c|}
\hline \multicolumn{2}{|c|}{ Direct evidence of suppuration. } & \multicolumn{2}{|c|}{ Presumption of suppuration. } & \multicolumn{2}{|l|}{$\begin{array}{l}\text { No evidence relating to } \\
\text { suppuration. }\end{array}$} \\
\hline $\begin{array}{l}\text { Purulent discharge } \\
\text { indicated in con- } \\
\text { nection with dis- } \\
\text { eased bone ......... } \\
\text { Cases described as ne- } \\
\text { crosis ............... } \\
\text { Chronic ulcers involv- } \\
\text { ing bone ............ } \\
\text { Scrofulous sores ....... } \\
\text { Scrofulous disease of } \\
\text { urinary organs...... } \\
\text { Phthisis (lung gener- } \\
\text { ally described as } \\
\text { disorganised) ...... } \\
\text { Syphilitic ulceration } \\
\text { of soft parts......... } \\
\text { Dysentery or ulcera- } \\
\text { tion of bowels ...... } \\
\text { Suppuration in pelvis } \\
\text { after labour .......... }\end{array}$ & $\begin{array}{r}24 \\
4 \\
2 \\
3 \\
3 \\
20 \\
6 \\
4 \\
2\end{array}$ & $\begin{array}{l}\text { Disease of bones or } \\
\text { joints, nature not } \\
\text { specified ............. } \\
\text { Syphilitic affection } \\
\text { of bone ............ } \\
\text { Syphilis; no descrip- } \\
\text { tion.................. } \\
\text { General tuberculosis. } \\
\text { Tubercular perito- } \\
\text { nitis ................ }\end{array}$ & $\begin{array}{l}\mathbf{7} \\
\mathbf{2} \\
\mathbf{2} \\
\mathbf{1}\end{array}$ & $\begin{array}{l}\text { Canse not ascer- } \\
\text { tained; chiefly } \\
\text { from incom- } \\
\text { pleteness of his- } \\
\text { tory .................. }\end{array}$ & 11 \\
\hline Total............ & 68 & Total .......... & 17 & Total ....... & 11 \\
\hline
\end{tabular}

In eleven of the number, from the incompleteness of the history and other circumstances, the origin of the disease was not discovered. Of the remaining eighty-five there were sixty-eight in which there was direct evidence of a suppurative drain, while in seventeen the nature of the post-mortem appearances gave a fair presumption that suppuration had gone on at a former period.

I have further been able to collect from three papers published by. Dr. Grainger Stewart the particulars of twentyseven cases of the amyloid change in which the body was 
examined after death. The results are given in a tabular form. Of twenty-four cases where the cause of the disease was traced, there was direct evidence of suppuration in fifteen, with a great probability of a past discharge of the same sort in the remaining nine.

\section{TABLE III.}

Analysis of twenty-seven cases of waxy or amyloid disease, showing the affections by which it has been preceded. Cases collected from papers by Dr. G. Stewart, in 'Edin. Monthly' for 1861 and 1864, and 'Brit. and For. Med.Chir. Rev.' for 1866.

\begin{tabular}{|c|c|c|c|c|c|}
\hline Direct evidence of suppuration & & Presumption of suppuratior & & $\begin{array}{l}\text { No evidence relating t } \\
\text { suppuration. }\end{array}$ & \\
\hline $\begin{array}{l}\text { Abscesses connected } \\
\text { with disease of } \\
\text { spine.................. } \\
\text { Necrosis of cranium } \\
\text { (syphilitic) ......... } \\
\text { Syphilitic ulceration } \\
\text { of soft parts......... } \\
\text { Advanced phthisis (in } \\
2 \text { of which bowels } \\
\text { ulcerated)............ } \\
\text { Suppurating bron- } \\
\text { chial glands with } \\
\text { deposits like tuber- } \\
\text { cles in lungs ..... } \\
\text { Ulceration of bowels } \\
\text { (no phthisis) ...... }\end{array}$ & \begin{tabular}{l|}
2 \\
1 \\
2 \\
8 \\
1 \\
1
\end{tabular} & $\begin{array}{c}\text { Hip disease of long } \\
\text { standing............ } \\
\text { Caries of vertebræ... } \\
\text { Long - standing sy- } \\
\text { philis, with de- } \\
\text { posits in viscera... } \\
\text { “ Signs of tubercu- } \\
\text { losis" in lungs } \\
\text { (stethoscopic) ... } \\
\text { Cicatrices or traces } \\
\text { of old deposit in } \\
\text { lungs .............. } \\
\text { Cancer in abdomen, } \\
\text { not particularly } \\
\text { described ........ } \\
\text { Marks, possibly cica- } \\
\text { trices of ulcers, in } \\
\text { bowels ............ }\end{array}$ & $\begin{array}{l}1 \\
1\end{array}$ & $\begin{array}{c}\text { Cause not ascer- } \\
\text { tained............. }\end{array}$ & 3 \\
\hline Total.......... 1 & 15 & Total ......... & 9 & Total ....... & $\overline{3}$ \\
\hline
\end{tabular}

These observers have recorded their experience apparently without any especial regard to suppuration. Thus, many cases which, had they been described fully, would have contained record of purulent discharge, are merely classed as tuberculosis, caries, or syphilitic disease of bone, and have therefore fallen into the class in which suppuration was presumed but not ascertained. 
Placing together the cases from both writers, we have 109 in which the antecedent disease was traced; of these 83, or more than three quarters, were consequent upon undoubted loss of pus, while in the remaining 26 the preceding disorders are of such a nature that it is not possible to doubt that the same morbid discharge must, at some period, have been present in the greater number.

If the existence of a protracted discharge of pus be ascertained in any case under treatment, even though there may be no symptom of "amyloid" disease, it may be surmised that some amount of the peculiar change will be found on post-mortem examination. And if in such a case there be albumen in the urine, or palpable enlargement of the liver, the existence of the "amyloid" deposit may be confidently assumed.

It is necessary to abandon the view that the disease in question is necessarily connected with any especial cachexia or specific disease.

Three of the cases which came under my own knowledge are instances in support of this remark.

A child, 6 years of age, was under my care at the Children's Hospital, for cough with purulent expectoration, which dated from an attack of whooping-cough four years before. Bubbling and cavernous sounds were heard in the lungs, and it was presumed that she had phthisis. While under treatment œdema appeared, and the urine was found to be albuminous. The existence of " amyloid" degeneration was inferred, and the treatment was modified accordingly. When, after death, the body was examined, the anticipated change was found in the liver, kidneys, and intestines. But the cause of the purulent expectoration was not phthisis. The lungs were full of cavities, some as large as walnuts, formed by dilatation of the bronchial tubes. There was not a tubercle in the body. The character of the expectoration in this case will be described subsequently. (See page 48.)

A life-guardsman while in perfect health received a severe compound fracture of the leg, his horse falling upon him. The wound healed slowly, after having suppurated for about 
two months. The man after a time recovered apparent health. Eventually, without any further cause, as far as could be ascertained, he was attacked with dropsy and albuminuria, of which he died nearly six years after the accident. The kidneys were preserved as specimens of the "large smooth kidney." Some years later, the concurrence of the renal disease with the injury suggested their true character, and on re-opening the preparation the iodine test showed them to be " amyloid" in a most marked degree.

The third case was that of a vigorous young man whose thigh was amputated in consequence of an accident by which the popliteal artery was torn. Most profuse suppuration followed the operation, and twenty-one days afterwards the patient died of pyæmia. The characteristic iodine-reaction was detected in the malpighian bodies of the kidneys.

Among Dr. Wilks's cases are two in which the disease followed suppuration in the pelvis consequent upon labour.

The relation which subsists between the subtraction of pus from the system, and the deposition of the new material in the organs, is the next step in the inquiry. It will be necessary to have regard to the composition of pus on the one hand, and of the so-called amyloid deposit on the other.

Pus is an albuminous fluid, which is alkaline, owing to the presence of a large amount of potass and soda. Earthy salts are also present, but in comparatively minute quantity. Fibrine is absent. It may be roughly estimated that the alkaline and earthy salts of pus amount to 1 per cent. of the discharge, and that of these the salts of potass and soda form about nine tenths. It will be shown afterwards that there are characters in the new deposit which draw attention in an especial manner to the alkalies. It is not necessary to repeat in this place details of analysis which are familiar to all pathologists. I have appended in a note some of the results which have been obtained by chemists. ${ }^{1}$

1 Note on the composition of pus.-Three analyses of pus were made by Dr. Wright ('Med. Times,' 1845), the discharge having been obtained respectively from a vomica, a psoas abscess, and a mammary abscess. The salts of the alkalies and lime varied, in 1000 parts, from 8.9 to 13.5 .

Analyses of pus are given in Simon's 'Chemistry' (Cavendish Society, 
In the case of dilated bronchi, followed by " amyloid" change (page 46), the child coughed up daily a quantity of pus, which did not vary much from 105 cubic centimetres, or about three ounces and a half.

\author{
Grms. \\ This contained $\cdot 922$ of mineral matter. \\ -867 of alkaline salts (about 13 grains). \\ .055 of earthy salts.
}

The alkalies amounted to-

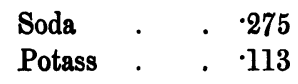

The above quantities represent the secretion of twenty-four hours.

In some pus obtained from a psoas abscess $I$ found that 100 parts contained, of potass $\cdot 504$, of soda 476 , the earthy salts, not analysed, amounting to $\cdot 2$.

From these particulars it appears, that not only does pus contain alkaline salts in the amount stated, but that these salts are much more abundant in pus than in the blood from which the secretion is derived. A discharge of pus is equivalent to a removal from the blood of albumen and alkali. Having regard to the great length of time for which the drain is sometimes continued, and the large daily amount

vol. 2, p. 91), in which the proportion of the soluble salts of pus to the insoluble is estimated in one case as 5 to 0.7 , in another as 4.7 to 0.62 .

The analyses made by Nasse of the serum of pus are compared with the serum of blood; the general results are as follow : In 1000 parts of the serum of blood the alkaline salts amounted to $7 \cdot 1$. In the same quantity of pus serum the alkaline salts amounted to $15 \cdot 32$, more than twice as much.

Lehman ('Physiological Chemistry,' Cavendish Society, vol. 2, p. 150) made comparisons between the composition of pus and of blood taken from the same animal, conducting his experiments upon wounded rabbits and geese. With rabbits he shows that while the ash of pus contains 6.9 per cent. of potass, the ash of the corresponding blood contains only 4.8 per cent. With geese the difference is still greater. This chemist infers that " the ash of pus always contains a larger amount of phosphates and potass salts than the inter-cellular fluid of the corresponding blood." 
which may be discharged, we may be prepared to expect consequent changes in the nutrition of the body.

What is true of a purulent discharge holds good in a modified degree with some forms of albuminuria. In albuminuria there is often a loss both of albumen and free alkali. It does not appear that the salts of the alkalies are more abundant in albuminous than in healthy urine; but albuminous urine is generally wanting in acidity, sometimes positively alkaline. Whether this arises from excess of alkali or deficiency of acid the same result must follow-a diminution of the free alkali of the blood.

I may now take into consideration the characters of the " amyloid" or "waxy" deposit. It is no longer necessary to discuss the theory which associates it with the development of starch. It has been already shown that the results of ultimate analysis, the contractile tendency of the new formation, its transformation into fibrous tissue, and its apparent identity with fibrinous casts, concur to prove that it is essentially fibrinous. But since fibrine does not, in a general way, give the characteristic reaction with iodine, it remains to be shown on what this reaction depends. In order to do so I must ask the attention of the Society to some chemical details.

The deep brown colour with iodine, which is characteristic of the "amyloid" disease, is constant under a variety of circumstances. The affected tissue may be dried, boiled, soaked in alcohol, in strong acids, or in caustic ammonia, and still the same striking colour is brought out by the same reagent. It is not affected by solutions of any of the alkaline salts; but if a section of an organ so diseased be allowed to remain for a short time in a dilute solution of caustic potass or soda, the colour soon disappears never to return. The destruction of the iodine reaction is permanent, although all removeable alkali be washed from the tissue; the reaction is not restored by the action of acid. The action of iodine becomes precisely what it is upon healthy structure. The minute quantity of potass or soda which the tissue takes up destroys the so-called amyloid reaction. The power of destroying the vol. $\mathbf{L}$. 
reaction is, as far as $I$ can ascertain, confined to caustic potass and soda: it does not extend to their salts, or to ammonia in any form.

After many experiments upon " amyloid" tissues, I learned that sulphate of indigo is a test for the deposit no less striking than iodine itself. If a piece of a healthy organ be soaked in a weak solution of this material it assumes a blue colour, which, after a time, fades into a pale greenish tint (Plate II, Fig. A). This change also takes place in the parts of an "amyloid" organ which escape the disease. Those portions, however, which are affected retain a deep brilliant blue which affords a striking contrast with the parts which are free from the morbid deposit. Thus it appears that the healthy tissue of the liver or kidney has a power of destroying the colour of sulphate of indigo, which the morbid deposit does not possess. The power of decolourising sulphate of indigo is known to belong to the caustic alkalies; under the circumstances described the destruction of colour appears to be due to the free alkali contained in the healthy tissues. The colour is retained in the morbid deposit, and in that only, because it is the only part without this component. The drawings (Plate II, Figs. $B$ and c) show the effect described.

I might adduce other arguments to show that the morbid deposit differs from healthy tissue in the absence from it of free alkali (the action of turmeric is characteristic) ; but it is not necessary to multiply observations in behalf of a conclusion which will be placed beyond doubt by the remaining steps of this inquiry.

I will now proceed to give the results of some analyses of " amyloid" as compared with healthy organs, undertaken with a view of ascertaining the proportion of potass and soda in each. The liver has been made use of for this purpose, because it contains a greater apparent amount of the morbid formation than can be found elsewhere. But even in this structure it must be borne in mind, that the deposit is interspersed through the normal structure of the gland, to which in most cases it bears but a sman proportion. 


\section{Table IV.}

Table showing per-centage of alkaline and earthy salts in seven "amyloid" livers.

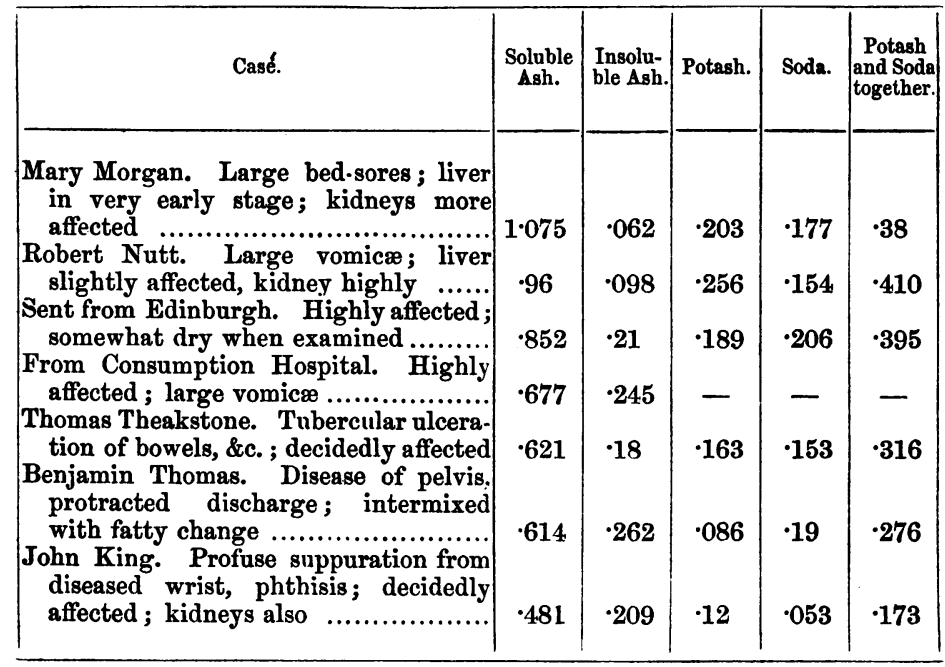

Average per-centages-Soluble ash, or total alkaline salts, $\cdot 754$; potash, $\cdot \mathbf{1 6 9}$; soda, $\cdot 156$.

Per-centage of alkaline and earthy salts in seven healthy livers.

\begin{tabular}{|c|c|c|c|c|c|}
\hline Case. & $\begin{array}{c}\text { Soluble } \\
\text { Ash. }\end{array}$ & $\begin{array}{l}\text { Insolu- } \\
\text { ble Ash. }\end{array}$ & Potash. & Soda. & $\begin{array}{c}\text { Potash } \\
\text { and Soda } \\
\text { together. }\end{array}$ \\
\hline $\begin{array}{c}\text { Liver of an adult; tissue apparently } \\
\text { natural } \\
\text { Ditto }\end{array}$ & $1 \cdot 181$ & .053 & $\cdot 187$ & .255 & $\cdot 442$ \\
\hline Liver of an adult; tissue slightly con- & & & 20 & 108 & 418 \\
\hline $\begin{array}{l}\text { gested } \\
\text { Liver of an adult; tissue apparently }\end{array}$ & $1 \cdot 041$ & $\cdot 033$ & $\cdot 205$ & .252 & $\cdot 457$ \\
\hline natural & .995 . & .016 & $\cdot 214$ & $\cdot 192$ & $\cdot 406$ \\
\hline 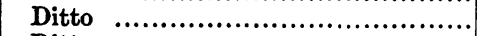 & .912 & .037 & .22 & .25 & .47 \\
\hline 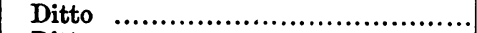 & .904 & .05 & $\cdot 191$ & $\cdot 123$ & .314 \\
\hline Ditto & .893 & .041 & .215 & $\cdot 164$ & $\cdot 379$ \\
\hline
\end{tabular}

Average per-centages-Soluble ash, or total alkaline salts, 1.00; potash, $\cdot 209$; soda, $\cdot 196$. 
It is not necessary to occupy the Society with details of analysis. It may be shortly stated that a certain weight of the organ, as removed from the body, was reduced to an ash, and the saline constituents extracted in the usual manner. In some cases the acids were estimated as well as the bases, but at present it is only necessary to pay'attention to the amount of alkali.

I have estimated the potass and soda in seven livers at different stages of the disease, and $I$ have, for the sake of comparison, examined in the same way seven healthy livers : the results are stated in a tabular form. The analyses, to facilitate comparison, are arranged according to the amount of alkaline salts.

It will be seen that the proportion of alkaline salts in the healthy organ does not undergo much variation, while in the " amyloid" it varies greatly in consequence of its irregular diminution. In the healthy specimens the alkaline salts varied between 89 and 118 parts in 1000 . With the amyloid the variation was between 48 and 107. Taking the amounts of potass and soda separately a similar statement will hold good. In the diseased state both are irregularly diminished. The amount of reduction will be best estimated by comparing, as regards each item, the average of health with the average of disease.

Taking the gross alkaline salts in 100 parts of the fresh liver, it appears that the average of health is exactly 1.00 ; the average of "amyloid," $\cdot 754$, a reduction of one quarter. Taking the alkalies by themselves the healthy average of potash is 209 ; the "amyloid" average, $\cdot 169$, a loss of one fifth. The healthy average of soda is 196 , the " amyloid" average, 156 , a loss also of one fifth.

Hence it appears that a given weight of the "amyloid" liver contains less potash and less soda than the same weight of the healthy liver by about one fifth. The alkalies continue to hold about their natural healthy proportion to each other.

It is worthy of remark that while the alkalies of the "amyloid" organ are diminished the earthy salts are increased. 
From what has been brought forward it seems that the reactions are due to the absence of alkali, while the formation is essentially fibrinous. Under these circumstances we ought to be able, by depriving fibrine of the alkali with which it is ordinarily combined, to manufacture a material which has the " amyloid" reaction; and this can be done.

Fibrine is soluble in dilute hydrochloric acid (0.6 in 1000). If the solution be evaporated to dryness at a low temperature, a substance is obtained which has all the reactions characteristic of "amploid" disease. The acid has necessarily deprived the fibrine of its alkali.

Ordinary fibrine comports itself with iodine and sulphate of indigo, as do the healthy tissues. It takes a yellow colour with iodine; indigo gives it a blue colour, which fades, and eventually is destroyed. Fibrine, which has been dealkalised by the process described, reacts precisely as does the morbid deposit. Iodine gives to it the rich red-brown, while the bright blue of indigo is retained for an indefinite time.

The same reactions are afforded by albumen which has been deprived of alkali by a similar method. The reactions are the same, though all free acid has been neutralised by carbonate of ammonia, showing that they are due to the absence of fixed alkali, not to the presence of the acid.

If it be wished to exhibit the characteristic reactions of " amyloid". deposit the artificial product answers the purpose extremely well, in consequence of the marked character of the colours produced.

Conclusions.-The so-called " amyloid" or " waxy" deposit consists of dealkalised fibrine. It is not necessary to repeat the facts which lead to the conclusion that the deposit is fibrinous. That it is wanting in alkali is shown by these considerations :

1. The morbid deposit loses its characteristic reactions when it has been allowed to absorb potass or soda.

2. Organs containing this deposit yield on analysis a smaller proportion of the alkalies than do the same organs in a state of health.

3. Ordinary fibrine or albumen can be made to exhibit all 
the peculiarities of "amyloid" tissue by depriving them of alkali by artificial means.

The morbid deposit is of the nature of a residuum; it occurs in cases where the system has been drained by an alkaline and albuminous discharge, the blood, therefore, containing an excess of fibrine with a deficiency of potass and soda. Possibly the removal of the alkali may occasion the deposition of the fibrine.

The most frequent cause by which this deposit is produced is suppuration, a cause which is active in at least five cases out of six. The loss of albumen by the urine has a feeble tendency of the same sort. What other causes produce the disorder, and whether there are conditions which render the system more than usually liable to be affected by such processes as have been designated, are questions as yet unanswered.

The frequency of " amyloid" disease, the obvious nature of its cause, and the readiness with which it can be detected during life, combine to give it great practical importance. It supplies a large proportion of the albuminuria which comes under the care of the physician, and it is of constant occurrence among surgical patients, modifying the course of disease and overruling the results of operations.

The term amyloid must fall into disuse as founded upon error. The terms waxy and lardaceous are applicable to the change produced in a few organs only, besides which, like most pathological adjectives derived from superficial and often imaginary resemblances, they have each been applied to more than one sort of morbid formation.

I venture to propose the word Depurative ${ }^{1}$ as significant of the process which is the most frequent source of the disease. Under this designation the false conceptions would be avoided which attach to the phrases by which the morbid change has hitherto been described, and a clear assertion would be made

1 It has been objected to this word that depurate is already in use in the sense of purify. This, however, appears to be of small consequence, since no confusion is likely to result. The fault rests with those who originally permitted the identity of root between the words pus and purus. 
of the great practical truth that in all cases of protracted suppuration the deposit in question is a probable contingency. The inquiry is not barren of a suggestion with regard to the medical treatment of a purulent discharge. Our endeavour must be to compensate for the loss sustained by the system. The diet may be regulated so as to include abundance of albuminous matter, while the alkalies and their vegetable salts may be given in due proportion, and according to the circumstances of the individual case.

In conclusion, I have to thank Dr. Wilks, Dr. Grainger Stewart, Dr. R. Douglas Powell, and Dr. G. C. Bright, who have provided me with specimens for examination; also Dr. Noad, who has given me much valuable assistance in the chemical part of the investigation. 


\section{DESCRIPTION OF PLATE I.}

Amyloid kidney, showing casts in situ, coloured by iodine in the same manner as the Malpighian bodies and small arteries. $\times 75$ diameters.

\section{DESCRIPTION OF PLATE II.}

FIG. $\mathrm{A} \times 50$ diameters. Section of a healthy kidney, coloured with indigo, showing the uniform fading.

FIg. B $\times 50$ diameters. Amyloid kidney; cortex, including capsular edge; coloured with indigo, showing the retention of colour on the affected parts, the Malpighian bodies.

Fig. c $\times 50$ diameters. "Amyloid" kidney coloured with indigo (medullary part), showing the retention of colour upon the affected vessels.

N.B. The three sections coloured with indigo were kept for the same time in the same solution. 


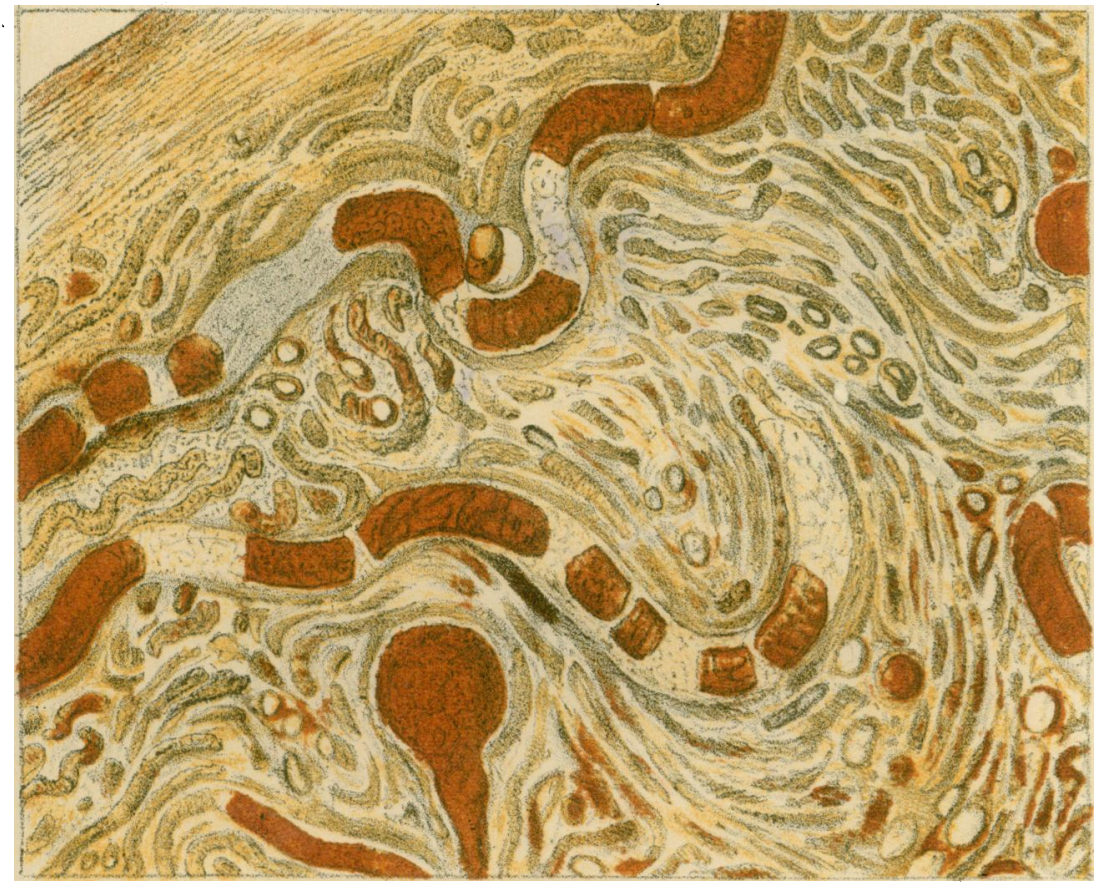


7) (1)

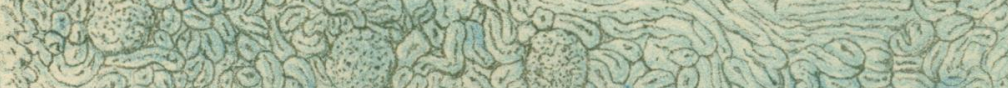
30 .

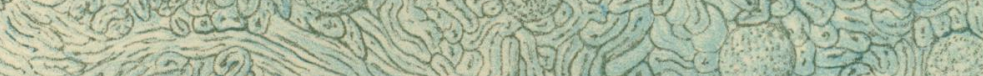

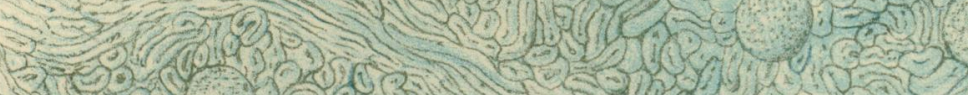

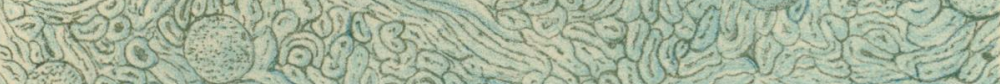

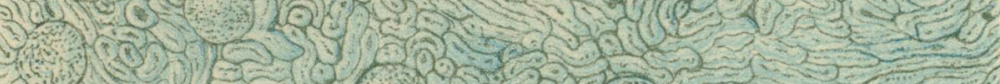

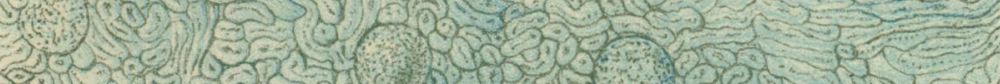

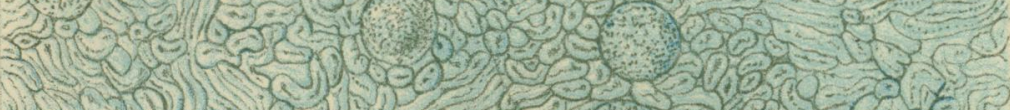

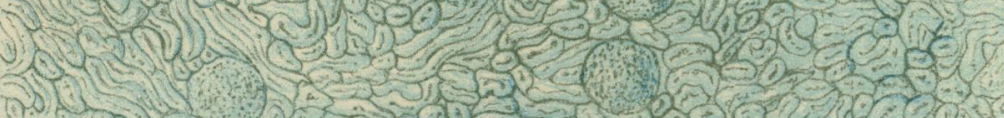
Q0. 1 का

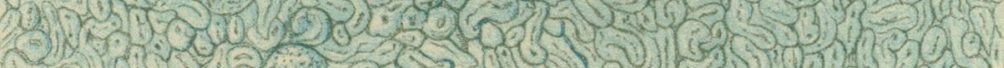
(Q)
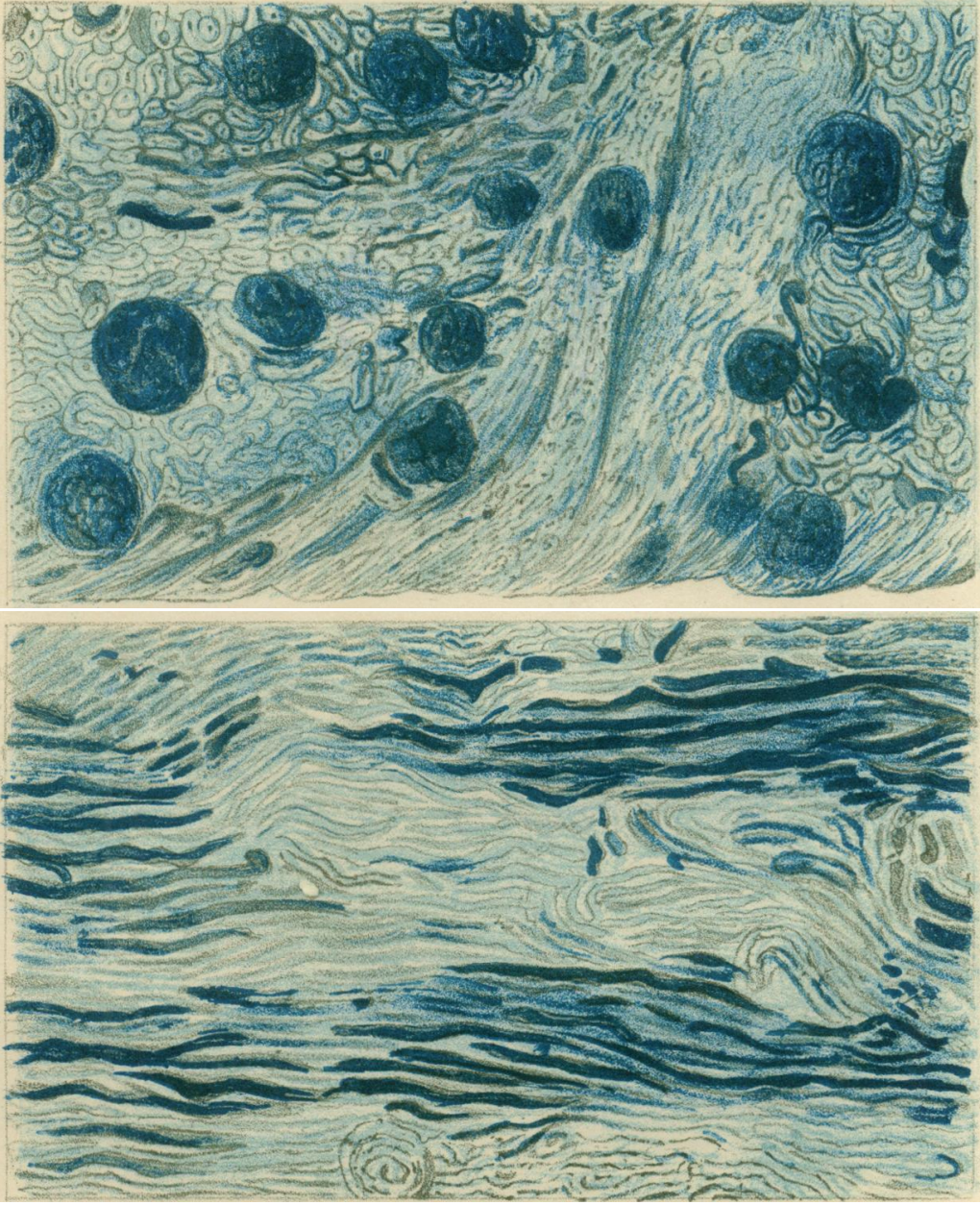